\title{
Variable Ethnic Frequency and Risk Ratio of DMPK Gene: A Meta-Analysis Survey
}

\author{
Ashok Kumar, Sarita Agarwal* and Sunil Pradhan
}

Department of Genetics and Department of Neurology, Sanjay Gandhi Post Graduate Institute of Medical Sciences, Lucknow, India

\begin{abstract}
Aim: Myotonic dystrophy type 1 (DM1) is due to CTG repeats in the 3'UTR region of DMPK gene. It has an incidence of 1 in 8000 in the Western European and North American populations and a lower incidence of 1 in 20,000 in Japan. However, prevalence of the disease in diverse Indian populations is still unknown.

Materials and Methods: The intention of the present study was to perform the meta-analysis to investigate the different ethnic frequency and risk ratio of DM1 in different populations of the world including India. Total twelve populations belong from Europeans, Asians and American were included in the present study. Meta-analyst was used for the analysis.

Results: The meta-analysis of the seven European populations demonstrated that Italian population had higher risk ratio in comparison to other studied population. Similarly, the three Asian populations demonstrated that South Indian population had higher risk ratio in comparison of North India and Korean population. In addition, the meta-analysis of two American population postulated that Canada had higher risk ratio in comparison of Brazil.
\end{abstract}

Conclusion: A vast ethnic variation in frequency of DMPK gene of different population of DM1, and expanded CTG repeat alleles as well as associated risk.

Keywords: Type 1 myotonic dystrophy; Dystrophia myotonica protein kinase; Meta-analysis; Forest plot

\section{Introduction}

Myotonic dystrophy (DM) is an autosomal dominant, multisystem trinucleotide repeat disorder. Myotonic dystrophy is clinically heterogeneous and at the molecular level at least two types can be distinguished: DM type 1 (DM1; Steinert disease) and DM type 2 [DM2; proximal myotonic myopathy (PROMM) or Ricker syndrome]. DM1 is the most common form of muscular dystrophy in adults with an estimated incidence of 1:8000 [1]. Two different mutations are responsible for DM: DM1 (OMIM \#160900) is caused by a (CTG) $\mathrm{n}$ repeat expansion in the 3 '-untranslated region of the DMPK gene located within chromosome band 19q13.3 [2,3] while DM2 (OMIM \#602688) is caused by a large (CCTG)n repeat expansion in intron 1 of the CNBP gene at chromosome $3 \mathrm{q} 21[4,5]$. The disorder shows a phenomenon of genetic anticipation in which affected individuals in succeeding generations have an earlier age of onset and a more severe clinical course [6] due to the expansion of the repeat number during gametogenesis.

The DMPK gene is $\sim 14 \mathrm{~kb}$ and encodes $2.3 \mathrm{~kb}$ of mRNA with 15 exons and the protein (cAMP-dependent serine-threonine kinase) of 624 amino acids $[7,8]$. The repeats in DMPK are repeats of CTG and vary in the normal population from 5 to 34 . The size more than 50 CTG is associated with DM1 and severity correlates with CTG repeat number [2,9-11].

On the basis of clinical symptoms DM1 was classified into four different subtypes: (i) mild (ii) classical (iii) juvenile and (iv) congenital types: (i) mild DM1: mildly symptomatic patients have premature cataracts and baldness as the sole clinical features. A late-onset myopathy develops and myotonia was only detectable by electromyography. Cardiac conduction abnormalities arise and result in a shorter life span [11], (ii) classical or adult-onset DM1: The age of onset is typically in the second or third decade of life. The most frequent symptoms are distal weakness, involving the long finger flexors of the arms and the dorsiflexors of the legs, leading to symptoms relating to the strength of hand grasping and an increased incidence of stumbling. In addition patients have cataracts, baldness and cardiac conduction abnormalities [11], (iii) juvenile DM1: this form resembles the classical form of myotonic dystrophy. However, it is more clearly associated with cognitive and behavioral abnormalities [11] and (iv) congenital DM1: Polyhydramnios and poor fetal movements precede the birth of an infant with congenital DM1 [11]. The affected parent is nearly always the mother and congenital DM1 occurs in a quarter of offspring of affected DM1 mothers [1].

The genetic testing of DM1 plays a critical role in characterizing them and directing clinical person to cater them for the appropriate therapy and management. Clinically, myotonic dystrophy is diagnosed by the elevated level of muscle enzyme SCK (serum creatinine kinase), characteristic pattern of electromyography peaks, nerve conduction velocity $(\mathrm{NCV})$ and various other parameters. PCR-RFLP $[12,13]$ followed by southern blotting [14-16] is used for the detection of CTG repeats. The TP-PCR (Triplet Primed-Polymerase Chain Reaction) technique was developed by group of Scientist [17] for screening the CAG repeat expansion in myotonic dystrophy and we are effectively using this reliable and rapid technique for the diagnosis of DM1 since last three years at our centre (Deptt. of Genetics, SGPGIMS) [18] The utility of TP-PCR in DM1 was shown in ref. $[19,20]$. It provides

*Corresponding author: Sarita Agarwal, Department of Genetics, Sanjay Gandh Post Graduate Institute of Medical Sciences, Lucknow-226014, India, Tel: 91522-2494349; Fax: 91-522-2668017; E-mail: saritasgpgi@gmail.com

Received July 20, 2015; Accepted September 07, 2015; Published September 09, 2015

Citation: Kumar A, Agarwal S, Pradhan S (2015) Variable Ethnic Frequency and Risk Ratio of DMPK Gene: A Meta-Analysis Survey. J Steroids Horm Sci 6: 160. doi:10.4172/2157-7536.1000160

Copyright: (c) 2015 Kumar A. This is an open-access article distributed under the terms of the Creative Commons Attribution License, which permits unrestricted use, distribution, and reproduction in any medium, provided the original author and source are credited. 
characteristic peak pattern which confirms the existence of triplet repeats in the $D M P K$ gene [17].

There is a great $D M P K$ gene ethnic variation among population of various parts of the world, as an example, DM1 has an incidence of 1 in 8000 in the Western European and North American populations [21] and a lower incidence of 1 in 20,000 in Japan [22]. However, prevalence of the disease in diverse Indian populations is still unknown. There is a positive correlation between the prevalence of the disease in different ethnic groups and the frequency of upper large-sized normal alleles $[23,24]$.

Therefore, the aim of the present study was to perform the metaanalysis to investigate the different ethnic frequency and risk ratio (RR) of DM1 in different populations of the world including India.

\section{Materials and Methods}

\section{Selection criteria}

Relevant studies were extracted from PubMed, Embase and Cochrane Library on December 31, 2014. The retrieval strings entered into these databases were: "(myotonic dystrophy type 1 and its frequency or DMPK gene frequency) and (Prevalance of myotonic dystrophy) and (susceptibility of myotonic dystrophy in different population)". If multiple publications for the same data from the same study group occurred, we only recruited the later dated paper into our final analysis.

\section{Inclusion and exclusion criteria}

Inclusion criteria: (1) A case-control study (2) The outcome had to be DM1 (3) There had to be at least two comparison groups (DM1 group vs. control group).

Exclusion criteria: (1) Review articles, editorials and case reports (2) Articles that did not provide detailed case-control data (3) Investigations on the association of other factors with DM1 (4) Investigations of the role of DMPK related to diseases. (5) Multiple publications of the same data from the same study group.

\section{Data extraction}

The following information was extracted from each study: first author, year of publication, 'race' of study population, number of cases and controls, detection method and disease severity (muscular impairment scale). In our studies, ethnicities were classified as Europeans, Asians and Americans.

\section{Statistical analysis}

The ethnic frequency of $D M P K$ gene was measured by the ORs together with the $95 \%$ CIs. The statistical software used for this analysis was Meta-analyst version 3.13.

\section{Results}

\section{Selection of studies and its characteristics}

Patients having complaint of muscle wasting, jaw and temporal wasting, impairment in gripping capacity, arrhythmia, facial weakness and hypersomnia included in the study while patients having any other neurological disorder or any other severe or familiar disease excluded from the study. Clinically, DM1 patients diagnosed on the basis of detailed history of disease, disease severity (muscular impairment scale), physical examination, biochemical testing and electrophysiological testing like NCV (Nerve conduction velocity), EMG (Electromyography) (Supplementary Figure S1 and Table 1) etc. while molecular detection was done in all patients by TP-PCR methodology [17] (Supplementary Figure S2 and Table 1). Blood samples were collected in EDTA and plain vials from 27 DM1 patients (median age 32.8 years \pm 9.3 , range 17-52) and 40 age and sex matched controls (median age 31.0 years \pm 8.6 , range 16-54) after written informed consent.

In this meta analysis, we have identified total 12 case-control studies (including our studies) of DM1. The studied populations belong from Europeans (7 populations), Asians (3 populations) and American (2 populations) continent (Table 1 ).

\section{Meta-analysis}

The ethnic frequency of $D M P K$ gene, susceptible for disease, in all studied populations of European, Asian and American were 100\% except from populations of Brazil (47.2\%), Korea (43.8\%) and North India (74.1\%) (Figure 1).

The meta-analysis of the 7 European populations (France, Germany, Morocco, Austria each had one population and three from Italy) demonstrated that Italian population had higher risk ratio in comparison to other studied population ( $\geq 3$ fold vs. $>1$ fold). However, France $(\mathrm{RR}=0.897)$ and Morocco $(\mathrm{RR}=0.853)$ populations had low risk ratio of DM1 (Figure 2). The meta-analysis of the 3 Asian populations (first from South India, second from North India and third from Korea) demonstrated that South Indian population had higher risk ratio in comparison of North India and Korean population (Figure 2). In addition, the meta-analysis of 2 American population [one from Canada (North America) and second from Brazil (South America)] postulated that Canada had higher risk ratio in comparison of Brazil ( 2 fold vs. $<1$ fold) (Figure 2).

\section{Discussion}

Myotonic dystrophy (DM) is a kind of progressive multisystemic autosomal dominant disorder with phenomena of anticipation; it denotes progressively earlier onset of the disease within successive generations. The disabilities are substantial and therefore early detection is mandatory for reproductive counselling of families in which the DM1 has been observed as they have $50 \%$ chances of each pregnancy to have an affected child. With respect to the genetic screening as well as diagnostics application, one of the commonly used detection approaches utilizes the combination of conventional PCR and triplet repeat-primed PCR [17-20,25-28]. The TP-PCR can detect the presence of long allele size without determining the total size of the expansion or the exact number of expansions CTG. TP-PCR method is routinely used by western countries for the diagnosis of DM1 while in India DM1 is clinically diagnosed only.

There are two principal objectives of this study. First, we report frequencies of $D M P K$ genes in some population samples of diverse ethnic and geographic origin of the world. Second, our analysis estimated the risk ratio in these populations.

The higher incidence of European populations directly correlated with the repeat size greater than 19 which is seen in these populations and due to higher CTG repeat the risk ratio is also higher [29]. For an example, the study performed in ref. [30]. In the samples of DM1, the higher incidence of DM1 falls in the category of E2 (50\% had 200700 CTG repeat) and E3 (27\% had $>700$ repeat) [30]. In case of Indian population, the severity score ranging from 8 to 38 (while the severity score range is $0-70$ ) suggesting a mild to moderate severity. The studies from NIMHANS (Bangalore, South India) [28] and Saha Institute of 
Citation: Kumar A, Agarwal S, Pradhan S (2015) Variable Ethnic Frequency and Risk Ratio of DMPK Gene: A Meta-Analysis Survey. J Steroids Horm Sci 6: 160 . doi:10.4172/2157-7536.1000160

Page 3 of 4

\begin{tabular}{|c|c|c|c|c|c|c|c|c|c|c|c|c|}
\hline \multirow{2}{*}{$\begin{array}{l}\text { First author } \\
\text { (year) }\end{array}$} & \multirow{2}{*}{ Country } & \multirow{2}{*}{ Ethnicity } & \multicolumn{2}{|c|}{ No. of subject } & \multicolumn{2}{|c|}{ Sex M/F/Fetus } & \multicolumn{2}{|c|}{ Age (mean \pm SD) } & \multirow{2}{*}{$\begin{array}{c}\text { Disease } \\
\text { duration } \\
\text { (year) }\end{array}$} & \multirow{2}{*}{$\begin{array}{c}\text { Detection } \\
\text { method }\end{array}$} & \multirow{2}{*}{$\begin{array}{l}\text { CTG Repeat } \\
\text { length }\end{array}$} & \multirow{2}{*}{$\begin{array}{c}\text { Disease } \\
\text { severity } \\
\text { (Muscular } \\
\text { Impairment } \\
\text { Scale) }\end{array}$} \\
\hline & & & $\begin{array}{c}\text { Cases/+ve } \\
\text { cases }\end{array}$ & Control & Cases & Control & Cases & Control & & & & \\
\hline $\begin{array}{c}\text { Catherine et al., } \\
\text { (1992) }\end{array}$ & Canada & Canadian & $272 / 272$ & 140 & - & - & - & - & - & $\begin{array}{c}\text { PCR-Southern } \\
\text { blotting }\end{array}$ & - & - \\
\hline $\begin{array}{c}\text { Martina et al., } \\
(2011)\end{array}$ & Germany & German & $22 / 22$ & 22 & $9 / 13$ & $11 / 11$ & $\begin{array}{c}43.1 \pm \\
12.6\end{array}$ & $\begin{array}{c}50.1 \pm \\
9.0\end{array}$ & $13.2 \pm 7.0$ & $\begin{array}{c}\text { PCR-Southern } \\
\text { blotting }\end{array}$ & $\begin{array}{l}614 \pm 306 \\
(80-1100)\end{array}$ & $3.6 \pm 0.9(1-5)$ \\
\hline $\begin{array}{l}\text { Gharehbaghi- } \\
\text { Schnel et al., } \\
\quad(1998)\end{array}$ & Austria & Austrian & $18 / 18$ & 26 & $11 / 7$ & - & 39.2 & - & - & $\begin{array}{c}\text { PCR-Southern } \\
\text { blotting }\end{array}$ & $\begin{array}{c}2439(300- \\
6000)\end{array}$ & $2.94(1-5)$ \\
\hline $\begin{array}{l}\text { Siciliano et al., } \\
(2001)\end{array}$ & Italy & Italian & 199/199 & - & $116 / 83$ & - & $\begin{array}{l}45.9 \pm \\
17.4\end{array}$ & - & - & $\begin{array}{c}\text { PCR-Southern } \\
\text { blotting }\end{array}$ & - & - \\
\hline $\begin{array}{l}\text { Giovanni et al., } \\
(2006)\end{array}$ & Italy & Italian & $20 / 20$ & 20 & $11 / 9$ & $11 / 9$ & 37 & - & 12 & - & $\begin{array}{c}461 \pm 365 \\
(100-1570)\end{array}$ & $2.75(1-5)$ \\
\hline $\begin{array}{l}\text { So Yeon Kim et } \\
\text { al., (2008) }\end{array}$ & Korea & Korean & $283 / 124$ & 47 & $71 / 52 / 1$ & - & - & - & - & $\begin{array}{c}\text { PCR-Southern } \\
\text { blotting }\end{array}$ & $\begin{array}{l}480(50- \\
2770)\end{array}$ & - \\
\hline $\begin{array}{l}\text { Maria Rita et al., } \\
\text { (1995) }\end{array}$ & Brazil & Brazilian & $235 / 111$ & 120 & - & - & - & - & - & $\begin{array}{c}\text { PCR-Southern } \\
\text { blotting }\end{array}$ & $\begin{array}{l}1770(100- \\
9000)\end{array}$ & - \\
\hline $\begin{array}{c}\text { Christine } \\
\text { Delaporte (1998) }\end{array}$ & France & Fransisi & $15 / 15$ & 14 & $6 / 9$ & - & 35 & 35.7 & & $\begin{array}{c}\text { PCR-Southern } \\
\text { blotting }\end{array}$ & $(260-1000)$ & - \\
\hline $\begin{array}{l}\text { Khalil et al., } \\
(2010)\end{array}$ & Morocco & Morocco & $24 / 24$ & 30 & $14 / 10$ & - & - & - & - & $\begin{array}{l}\text { PCR-TP-PCR- } \\
\text { Southern blotting }\end{array}$ & - & - \\
\hline $\begin{array}{l}\text { M. Gouri devi et } \\
\text { al., (1998) }\end{array}$ & India & Indian & $19 / 19$ & - & $15 / 4$ & - & $\begin{array}{c}30.4 \pm \\
12.9\end{array}$ & - & $5.2 \pm 4.2$ & $\begin{array}{l}\text { PCR-Southern } \\
\text { blotting }\end{array}$ & $90-313$ & - \\
\hline $\begin{array}{l}\text { Toscano et al., } \\
2005\end{array}$ & Italy & Italian & $36 / 36$ & 22 & - & - & $27 \pm 11$ & $\begin{array}{c}32.5 \pm \\
11.9\end{array}$ & - & $\begin{array}{l}\text { PCR-Southern } \\
\text { blotting }\end{array}$ & $50->1500$ & - \\
\hline Present Study & India & Indian & $27 / 27$ & 40 & $16 / 4$ & $32 / 8$ & $\begin{array}{l}32.8 \pm \\
9.3\end{array}$ & $\begin{array}{c}31.0 \pm \\
8.6\end{array}$ & $6.9 \pm 4.8$ & PCR-TP-PCR & - & $2.87(1-5)$ \\
\hline
\end{tabular}

Table 1: General characteristics of the included studies in this meta-analysis.

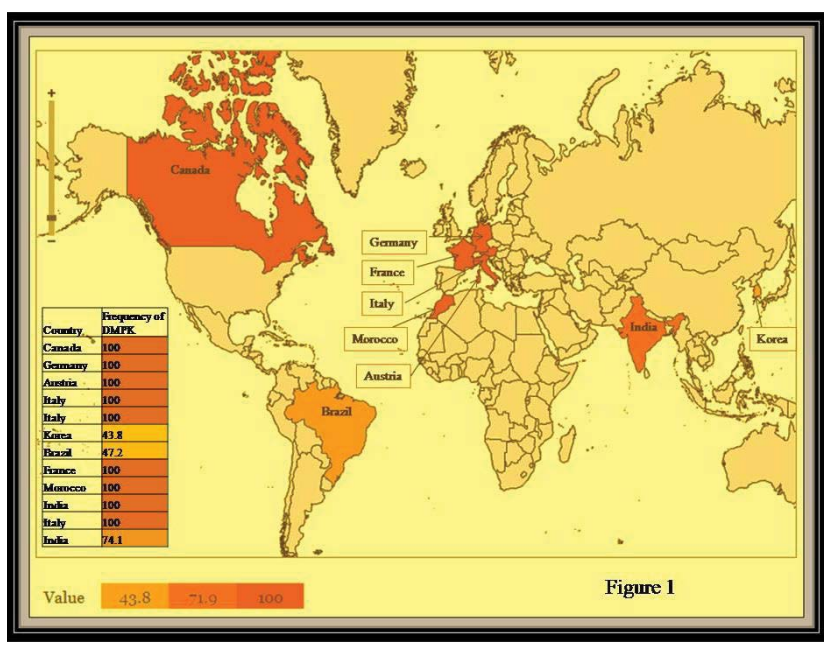

Figure 1: Differential frequency of DMPK gene for different population of the World. All, except population of Korea, Brazil and North India, have $100 \%$ ethnic frequency.

Nuclear Physics, Calcutta (East India) [31] reported that the frequency of CTG repeat greater than 19 was very low. This could explain the relatively low incidences of the disease in our population as the tool of such alleles, from which expansions are thought to occur, are less frequent. Our study from SGPGIMS, Lucknow (North India) had same concordance with the above findings.

Various published reports explain the frequency of expanded CTG repeat alleles ( $>19)$ in population of Europe, United States, Canada, or Japan [32-34] but there were very few reports from South America (eg.

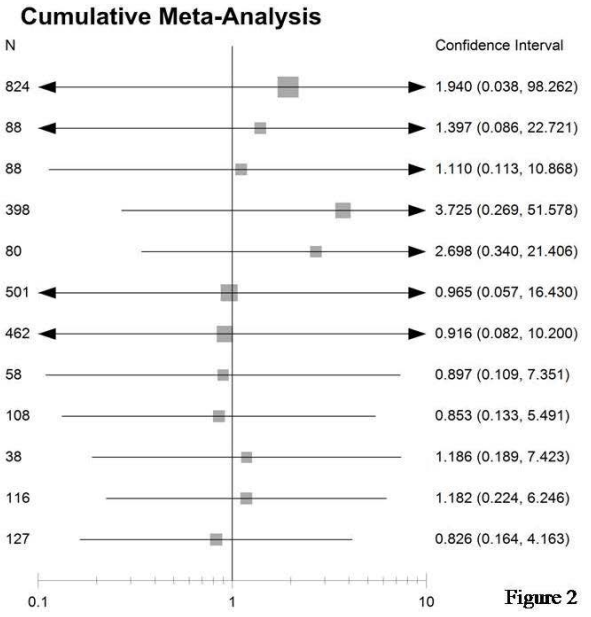

Figure 2: Forest plot represented the Odd Ratio showing the risk ratio between different case (DM1) and control populations of different ethnic group.

Canada). In Brazil, ethnic variability exists due to migrations from European and African populations, this migration having occurred mainly during the post-colonization period. According to ref. [35], 58\% of the immigrants who arrived in Brazil between 1500 and 1972 were Europeans, 40\% Africans and $2 \%$ Asiatics. Alleles with more than 18 repeats were found equally frequently in Rio de Janeiro (RJ) Brazilians (7.69\%) and other European populations (7.63\%) $[24,36]$.

The similar allele profile between Europeans and RJ-Brazilians, especially as regards the risk alleles (8\% for the Europeans and 7\% for the RJ-Brazilians), suggests a high prevalence of DM occurs in Rio de Janeiro, but until now few clinical reports of this disease have been described in this city. 
In conclusion, there is a vast ethnic variation in frequency of $D M P K$ gene of different population of DM1, and expanded CTG repeat alleles as well as associated risk.

\section{Acknowledgements}

Authors are thankful to Sanjay Gandhi Post Graduate institute of Medical Sciences (SGPGIMS), Lucknow (Uttar Pradesh, INDIA) and Department of Biotechnology (DBT), New Delhi, India for providing infrastructure facilities. Ashok Kumar is thankful to DBT, New Delhi for his fellowship (DBT-JRF: 2009-10/515).

\section{Declaration of Interest}

The authors report no conflicts of interest. The authors alone are responsible for the content and writing of the paper.

\section{References}

1. Harper PS (2001) Myotonic Dystrophy, (3rdedn) Harcourt Publishers Ltd. London.

2. Brook JD, McCurrach ME, Harley HG, Buckler AJ, Church D, et al. (1992) Molecular basis of myotonic dystrophy: expansion of a trinucleotide (CTG) repeat at the 3 ' end of a transcript encoding a protein kinase family member Cell 68: 799-808.

3. Fu YH, Pizzuti A, Fenwick RG, King J, Rajnarayan S, et al. (1992) An unstable triplet repeat in a gene related to myotonic muscular dystrophy. Science 255 1256-1258.

4. Liquori CL, Ricker K, Moseley ML, Jacobsen JF, Kress W, et al. (2001) Myotonic dystrophy type 2 caused by a CCTG expansion in intron 1 of ZNF9. Science 293: 864-867.

5. Ranum LP, Day JW (2002) Myotonic dystrophy: clinical and molecular parallels between myotonic dystrophy type 1 and type 2 . Curr Neurol Neurosci Rep 2: $465-470$

6. Howeler CJ, Busch HFM, Geraedts JPM, Neirmeijer MF, Staal A (1989) Anticipation in myotonic dystrophy: fact or fiction? Brain 112: 779-79.

7. Mahadevan MS, Amemiya C, Jansen G, Sabourin L, Baird S, et al. (1993) Structure and genomic sequence of the myotonic dystrophy (DM kinase) gene. Hum Mol Genet 2: 299-304.

8. Shaw DJ, McCurrach M, Rundle SA, Harley HG, Crow SR, et al. (1993) Genomic organization and transcriptional units at the myotonic dystrophy locus. Genomics 18: 673-679.

9. Mahadevan M, Tsilfidis C, Sabourin L, Shutler G, Amemiya C, et al. (1992) Myotonic dystrophy mutation: an unstable CTG repeat in the $3^{\prime}$ untranslated region of the gene. Science 255: 1253-1255

10. Kumar A, Agarwal S, Agarwal D, Phadke S (2013) Myotonic dystrophy type 1 (DM1): A triplet repeat expansion disorder. Gene 522: 226-230.

11. Kamsteeg EJ, Kress W, Catalli C, Hertz JM, Baumgartner MW, et al. (2012) Best practice guidelines and recommendations on the molecular diagnosis of myotonic dystrophy types 1 and 2. Eur J Hum Genet 20: 1203-1208.

12. Sermon K, Lissens W, Joris H, Seneca S, Desmyttere S, et al. (1997) Clinica application of preimplantation diagnosis for myotonic dystrophy. Prenat Diagn 17: $925-932$

13. Shaw DJ, Meredith AL, Sarfarazi M, Huson SM, Brook JD, et al. (1985) The apolipoprotein gene $\mathrm{C} 2$ gene: subchromosomal localization and linkage to the myotonic dystrophy locus. Hum Genet 70: 271-273.

14. Goossens V, De Rycke M, De Vos A, Staessen C, Michiels A, et al. (2008) Diagnostic efficiency, embryonic development and clinical outcome after the biopsy of one or two blastomeres for preimplantation genetic diagnosis. Hum Reprod 23: 481-492.

15. Sermon K, De Vos A, Van de Velde H, Seneca S, Lissens W, et al. (1998) Fluorescent PCR and automated fragment analysis for the clinical application of preimplantation genetic diagnosis (Steinert's disease). Mol Hum Reprod 4 : 791-796.

16. Sermon K, Seneca S, De Rycke M, Goossens V, Van de Velde H, et al. (2001) PGD in the lab for triplet repeat diseases-myotonic dystrophy, Huntington's disease and fragile-X syndrome. Mol Cell Endocrinol 183: S77-S85.
17. Warner JP, Barron LH, Goudie D, Kelly K, Dow D, et al. (1996) A general method for the detection of large CAG repeat expansions by fluorescent PCR. J Med Genet 33: 1022-1026.

18. Kumar A, Agarwal S, Phadke S, Pradhan S (2014) Application of a reliable and rapid polymerase chain reaction based method in the diagnosis of myotonic dystrophy type 1 (DM1) in India. Meta Gene 2: 106-113.

19. Radvansky J, Ficek A, Kadasi L (2011) Upgrading molecular diagnostics of myotonic dystrophies: multiplexing for simultaneous characterization of the DMPK and ZNF9 repeat motifs. Mol Cell Probes 25: 182-185.

20. Radvansky J, Ficek A, Minarik G, Palffy R, Kadasi L (2011) Effect of unexpected sequence interruptions to conventional PCR and repeat primed PCR in myotonic dystrophy type 1 testing. Diagn Mol Pathol 20: 48-51.

21. Harper PS (1989) Myotonic Dystrophy. (2ndedn) Saunders, London and Philedelphia.

22. Davies J, Yamagata H, Shelbourne P, Buxton J, Ogihara T, et al. (1992) Comparison of the myotonic dystrophy associated CTG repeat in European and Japanese populations. J Med Genet 29: 766-769.

23. Deka R, Majumder PP, Shriver MD, Stivers DN, Zhong $Y$, et al. (1996) Distribution and evolution of CTG repeats at the myotonin protein kinase gene in human populations. Genome Res 6: 142-154

24. Tishkoff SA, Goldman A, Calafell F, Speed WC, Deinard AS, et al. (1998) A global haplotype analysis of the myotonic dystrophy locus: implications for the evolution of modern humans and the origin of myotonic dystrophy mutations. Am J Hum Genet 62: 1389-1402.

25. Hamzi K, Bellayou H, Slassi I, Nadifi S (2010) "A rapid polymerase chain reaction-based test for screening Steinert's disease (DM1)," Neurol India 58: 99-102.

26. Addis M, Serrenti M, Meloni C, Cau M, Melis MA (2012) "Triplet-primed PCR is more sensitive than southern blottinglong PCR for the diagnosis of myotonic dystrophy type 1." Genet Test Mol Biomarkers 16: 1428-1431.

27. Li Y, Da YW (2012) "Detection for trinucleotide repeats in myotonic dystrophy type 1," Zhonghua Yi Xue Yi Chuan Xue Za Zhi 29: 16-18.

28. Kumar A, Agarwal S, Phadke S, Pradhan S (2014) Application of a reliable and rapid polymerase chain reaction based method in the diagnosis of myotonic dystrophy type 1 (DM1) in India. Meta Gene 2: 106-113.

29. Devi MG, Chaudhary JR, Vasanth A, Saleem Q, Mutsuddi M, et al. (1998) Correlation of clinical profile of myotonic dystrophy with CTG repeats in the myotonin protein kinase gene. Indian J Med Res 107: 187-196.

30. Siciliano G, Manca ML, Gennarelli M, Angelini C, Rocchi A, et al. (2001) Epidemiology of myotonic dystrophy in Italy: re-apprisal after genetic diagnosis Clin Genet 59: 344-349.

31. Basu P, Gangopadhaya PK, Mukherjee SC, Das SK, Sinha K, et al. (2000) Molecular anatomy of CTG expansion in myotonin protein kinase gene among myotonic dystrophy patients from eastern India. Hum Mutat 16: 372

32. Tsilfidis C, MacKenzie AE, Mettler G, Barcelo J, Komeluk RG (1992) Correlation between CTG trinucleotide repeat length and frequency of severe congenita myotonic dystrophy. Nature Genet 1: 192-5.

33. Harley HG, Rundle SA, MacMillan, JC, Myring J, Brook JD, et al. (1993) Size of the unstable CTG repeat sequence in relation to phenotype and parental transmission in myotonic dystrophy. Am J Hum Genet 52: 1164-1174.

34. Brunner HG, Bruggenwirth HT, Nillesen W, Jansen G, Hamel BCJ, et al. (1993) Influence of sex of the transmitting parent as well as of parental allele size on the CTG expansion in myotonic dystrophy (DM). Am J Hum Genet 53: 10161023

35. Callegri-Jacques SM, Salzano FM (1999) Brazilian Indian/ non-Indian interactions and their effects. Ciênc Cult 51: 166-174.

36. Zerylnick C, Torroni A, Sherman SL, Warren ST (1995) Normal variation at the myotonic dystrophy locus in global human populations. Am J Hum Genet 56 123-130. 